\title{
Immunoblotting analyses using two-dimensional gel electrophoresis of Trypanosoma cruzi excreted-secreted antigens
}

\author{
Análise de antígenos excretados-secretados de Trypanosoma cruzi \\ por immunoblotting em gel bidimensional
}

\section{Adriano Gomes Silva ${ }^{1}$, Elisangela Paula Silveira-Lacerda ${ }^{2}$, Jair Pereira Cunha-Júnior ${ }^{1}$, Maria Aparecida de Souza ${ }^{1}$ and Silvio Favoreto Junior ${ }^{1}$}

\begin{abstract}
Trypanosoma cruzi trypomastigotes excrete-secrete a complex mixture of antigenic molecules. This antigenic mixture denominated trypomastigote excreted-secreted antigens contains a 150-160 kDa band that shows excellent performance in Chagas' disease diagnosis by immunoblotting. The present study partially characterized by two-dimensional gel electrophoresis the immunoreactivity against the 150-160kDa protein using sera samples from chagasic patients in different phases of the disease. Trypomastigote excreted-secreted antigen preparations were subjected to high-resolution twodimensional (2D) gel electrophoresis followed by immunoblotting with sera from chagasic and non-chagasic patients. The 150-160kDa protein presented four isoforms with isoelectric focusing ranging from 6.2 to 6.7 . The four isoforms were recognized by IgMfrom acute phase and IgG from chronic phase sera of chagasic patients. The 150-160kDa isoform with IF of approximately 6.4 became the immunodominant spot with the progression of the disease. No cross-reactivity was observed with non-chagasic or patients infected with Leishmania sp. In this study we provide basic knowledge that supports the validation of trypomastigote excreted-secreted antigens for serological diagnosis of Chagas' disease.
\end{abstract}

Key-words: Trypanosoma cruzi. Excreted-secreted antigens. Two-dimensional gel electrophoresis. Immunoblotting.

\section{RESUM0}

Formas tripomastigotas de Trypanosoma cruzi excretam/secretam uma complexa mistura de moléculas antigênicas. Essa mistura é chamada trypomastigote excreted-secreted antigens e contém uma banda de massa molecular em torno de 150-160kDa que possui excelente performance para diagnóstico de doença de Chagas em immunoblotting. No presente estudo foi caracterizado parcialmente, por gel bidimensional, a proteína de 150-160kDa pela análise da reatividade de anticorpos de pacientes chagásicos nas diversas fases da doença. Proteínas do trypomastigote excreted-secreted antigens foram separadas por eletroforese de alta resolução em duas dimensões (2D) e submetidas a immunoblotting com soros de pacientes chagásicos e não chagásicos. A proteína de 150-160kDa foi identificada em quatro isoformas com pontos isoelétricos variando entre 6,2 a 6,7. As quatro isoformas foram reconhecidas por anticorpos IgMna fase aguda e por anticorpos IgG na fase crônica da doença de Chagas. A isoforma de 150-160kDa, com ponto isoelétrico de aproximadamente 6,4 tornou-se imunodominante dentre as demais com a progressão da doença. Năo foi detectada reatividade cruzada com os soros de pacientes não chagásicos ou pacientes infectados com Leishmania sp. Os dados obtidos nesse trabalho, reforçam a importância da utilização do trypomastigote excreted-secreted antigens para o diagnóstico sorológico da doença de Chagas.

Palavras-chaves: Trypanosoma cruzi. Antígenos excretados/secretados. Eletroforese em duas dimensões. Immunoblotting.

1. Laboratório de Imunologia do Instituto de Ciências Biomédicas da Universidade Federal de Uberlândia, Uberlândia, MG. 2. Instituto de Ciências Biológicas da Universidade Federal de Goiás, Goiânia, G0. 3. Departamento de Ciências Biológicas da Universidade Estadual de Santa Cruz, Ilhéus, BA, Brasil

Apoio financeiro: CNPq.

Address to: Dr. Silvio Favoreto Junior. R. Espírito Santo 314/21, 38440-660 Uberlândia, MG, Brasil.

Tel: 5534 3232-4239

e-mail: favoretojr@ hotmail.com

Recebido para publicação 10/11/2003

Aceito em 20/8/2004 
Chagas' disease caused by Trypanosoma cruzi, is still a major health problem in Latin America. Despite the decrease in incidence and prevalence in endemic areas ${ }^{2627}$, the World Health Organization has estimated 16-18 million infected people and approximately 90 million individuals undeniably living at risk of contact with T. cruzi $^{20}$. The debilitating morbidity among these infected persons remains a serious obstacle to health and economic development in Latin America, particularly in poor rural areas.

Currently, the procedures available for control of Chagas' disease are limited. There are no vaccines available and curative measures are restricted to two drugs. Chemotherapy is most effective during the acute and early chronic phase of infection, buthas several adverse effects and may not always eliminate the parasite ${ }^{6}$.

The acute phase of Chagas' disease follows the introduction of infective forms by vector transmission or contaminated blood transfusion. High number of parasites in the bloodstream, fever, adenomegaly and presence of specific IgM antibodies characterize this phase. However, these symptoms are not frequently observed in endemic areas, where the infection usually has a benign clinical course leading to an indeterminate phase ${ }^{1924}$. Later in life, $15-20 \%$ of individuals in this indeterminate asymptomatic phase evolve to a severely incapacitating chronic phase, the triggering factors for this outcome remain unknown ${ }^{8}$.

Serological diagnosis of american trypanosomiasis currently relies upon indirectimmunofluorescence, indirecthemagglutination and enzyme-linked immunosorbent assay (ELSA). Most of the commercial tests currently available use whole or semi-purified fractions of T. cruzi epimastigotes as the source of antigen. Despite a high sensitivity for antibody detection in chronic patients, epimastigote antigens produce false positive reactions and produce cross-reactivity with sera from patients with other infections, mainly leishmaniasis ${ }^{5}$. Thus, several authors have used recombinantantigens for Chagas' disease screening ${ }^{16}{ }^{28} 29$. However, the variation in sensitivity, specificity, antigenic preparation and standardization of reagents and procedures reported by different laboratories leads to a considerable percentage of unsatisfactory results that need to be confirmed by other methods ${ }^{311}$. This is a critical issue for blood banks, as none of the methods available can be considered sufficiently sensitive for an efficient donor screening of Chagas' disease ${ }^{21}$.

Trypomastigote forms of the parasite secrete several antigens into the supernatant of infected cells in culture that includes glycosidase ${ }^{23}$, glycosyltransferases ${ }^{4}$ and proteases ${ }^{2}{ }^{13}{ }^{33}$. This mixed group of molecules is recognized by antibodies produced during the acute and chronic phase of Chagas' disease ${ }^{149}$ and generally is named trypomastigote excreted-secreted antigens (TESA) ${ }^{30}$. When these secreted antigens are used to identify antibody populations present in the serum of chronic patients by immunoblotting, a 150-160 $\mathrm{kDa}$ protein is recognized from $100 \%$ of chronic chagasic sera and displays no cross-reactivity with other parasitic diseases ${ }^{2130}$. Recent reports have shown that TESA utilized in ELSA assays result in excellent sensitivity and specificity for Chagas' diagnostic, in both acute and chronic patients ${ }^{31}$.

Our aim in this study was to partially characterize the 150-160 kDa component of TESA using high resolution two- dimensional electrophoresis for protein separation and sera from patients in different phases of T. cruzi infection as probes. We hope to provide basic knowledge that could support the validation of TESA for serological diagnosis of Chagas' disease.

\section{MATERIAL AND METHODS}

Human sera. We collected sera samples from 25 chagasic seropositive patients and 20 non-chagasic seronegative patients from Brazil. Among the selected chagasic patients, ten were in chronic phase, with positive serology for Chagas' disease following the criteria utilized for blood donors screening (indirect immunofluorescence and ELSA). All chronic patients' presented negative results for specific IgM and both tests were positive for IgG; physical examination and electrocardiographywere performed for clinical assessment. Early acute patients included one case of accidental laboratory infection and four cases of vectorial transmission. Clinical symptoms, parasitological tests and presence of specific IgM established the presence of acute disease. These five patients had either absent or low levels of specific IgG as detected by conventional serology, which in addition to clinical and epidemiological data, allowed their classification as earlyacute infection. Ten cases of vectorial transmission presenting with high titers of specific IgM and IgG were classified as late acute infection irrespective of the presence or absence of clinical symptoms. The twenty non-chagasic seronegative patients consisted of ten cases of cutaneous leishmaniasis and ten healthy blood donors included as negative controls. All sera samples were preserved in $\mathrm{pH} 7.2$ buffered glycerol $(\mathrm{v} / \mathrm{v})$ and aliquots were stored at $-20^{\circ} \mathrm{C}$ to avoid protein degradation ${ }^{28}$. The research protocol presented in this manuscript and the consent forms for sample collection and utilization were approved by the Committee for Human Research - Federal University of Uberlandia and Hemominas.

Antigen preparation. TESA were obtained essentially as described ${ }^{30}$. Briefly, trypomastigotes of the $Y$ strain were maintained by serial passages in Swiss mice. The blood collected on the seventh day after inoculation was used to infect HEP-2 cell monolayers maintained in DMEM enriched with $10 \%$ fetal calf serum ( FCS). Following incubation for three days at $37^{\circ} \mathrm{C}$ in $5 \% \mathrm{CO}_{2}$, the culture was gently rinsed three times with DMEM and the medium was changed to DMEM 1\% FCS. The culture supernatants (TESA) were collected on post-infection day 6 $\left(\sim 10^{7}\right.$ parasites.ml ${ }^{-1)}$ then centrifuged at $2800 \mathrm{xg}$ for $10 \mathrm{~min}$ at $4^{\circ} \mathrm{C}$ and filtered through a $0.22 \mu \mathrm{m}$ pore size cellulose acetate membrane. Protease inhibitors cocktail ( $1 \mathrm{mM}$ PMSF, $0.5 \mathrm{mg}^{-\mathrm{ml}^{-1}}$ aprotinin, and $0.5 \mathrm{mg}_{\mathrm{m}} \mathrm{m}^{-1}$ leupeptin) was added to TESA and aliquots were stored at $-70^{\circ} \mathrm{C}$. The specific concentration of TESA in our preparations could not be determined by conventional assays due the content of proteins present in the medium, such as albumin.

One and two-dimension gel electrophoresis. The TESA were prepared for one-dimension SDS-PAGE (1D) by mixing 150 pl of culture supernatant with equal volume of SDSsample buffer ( $3 \%$ sodium dodecyl sulfate, $60 \mathrm{mM}$ Tris- $\mathrm{HCl}$ [ $\mathrm{pH}$ 
6.8], 5\% 2-mercaptoethanol, $10 \%$ glycerol and $0.01 \%$ bromophenol blue). The samples were boiled for $5 \mathrm{~min}$ at $100^{\circ} \mathrm{C}$ and loaded in a preparative $7 \%$ polyacrylamide gel. For two-dimensional gel electrophoresis (2D), the supernatants were diluted (1:3) in isoelectric focusing sample buffer ( $8 \mathrm{M}$ urea, $4 \%$ CHAPS, 18mM DTT, 2\% Pharmalite 3-10). The first-dimension isoelectric focusing ( IEF) was carried out using Immobiline Dry Strip ( pH 4-7L, 7cm long, Pharmacia Biotech) in a Multiphor II electrophoresis system (Pharmacia Biotech, NewJersey, USA). The isoelectric focusing was performed at $20^{\circ} \mathrm{C}$ with the following program: 500V for $1 \mathrm{~min}, 500$ - 3,500V rising gradient over $90 \mathrm{~min}$, and 3,500V for $4 \mathrm{~h}$. After completion of the first dimension procedure, the gel strips were incubated in equilibration buffer at room temperature for $15 \mathrm{~min}(50 \mathrm{mM}$ Tris-HCl [pH 6.8], 6M urea, 2\% [w/v] SDS, 30\% glycerol, 0.01\% bromophenol blue and $130 \mathrm{mM}$ dithiothreitol (DTT). This was followed by another incubation in equilibration buffer that contained $150 \mathrm{mM}$ iodoacetamide instead of DTT. The equilibrated gel strips were placed on top of 7\% SDS-polyacrylamide gels and the electrophoresis was conducted at $60 \mathrm{~V}$ and $10^{\circ} \mathrm{C}$.

Immunoblotting. The proteins separated in the 1D and 2D PAGE gels were transferred onto polyvinylidene difluoride membrane (PVDF, millipore). The membranes were blocked with 5\% defatted milk in PBS for 2 hours, then incubated overnight at $4^{\circ} \mathrm{C}$ with patient sera diluted 1:50 in PBS containing $1 \%$ defatted milk (PBS-M1\%). After washing, the blots were probed with goat anti-human IgG-peroxidase or anti-human IgM-peroxidase ( Sigma) in PBS-M1\% for 2 hours followed by a cycle of washes. Antigen-antibody reactions were observed after detection of peroxidase activity by $\mathrm{H}_{2} \mathrm{O}_{2}$ and diaminobenzidine ( Sigma).

\section{RESULTS}

In our one dimension immunoblotting assays with sera from early acute patients, IgM antibodies consistently recognized TESA proteins in a range of $80-200 \mathrm{kDa}$ in a ladder-like pattern ( Figure 1a). TESA-blot for specific IgGin these patients showed reactivity to proteins below $100 \mathrm{kDa}$ with a weaker overall intensity when compared to IgM assays ( Figure 1 b).

The patients grouped as late acute phase showed similarities on their TESA-blot pattern for specific IgM (Figure 1c) and IgG (Figure 1d). The $80-200 \mathrm{kDa}$ ladder-pattern was present in both assays. Interestingly, most of the patients in this group presented one band with approximately $160 \mathrm{kDa}$, included in the ladder pattern, that showed increased intensity when compared to the others at the same range of molecular weight.

Serological analysis of the chronic patients by one dimension TESA-blot showed an intense IgG reaction at 150-160 kDa in all tested samples ( Figure 1f). Some patient samples showed a few bands above this area and most of them recognized bands in the range of 80-120kDa. IgM specific assays with samples from these patients failed to recognize any TESA proteins as shown in Figure 1e.

No antibody reactivity was observed in TESA-blot using samples from healthy blood donors or patients with cutaneous leishmaniasis (data not shown).

Serum samples from early acute infection when analyzed by 2D TESA-blot showed a scattered IgM reaction ranging from pI 5.8 to 6.7 and 80 to $200 \mathrm{kDa}$. The ladder-like pattern observed in 1D TESA-blot revealed a larger number of spots in 2D analysis. IgM reactivity against the 150-160kDa protein was observed with poor definition towards the alkaline side

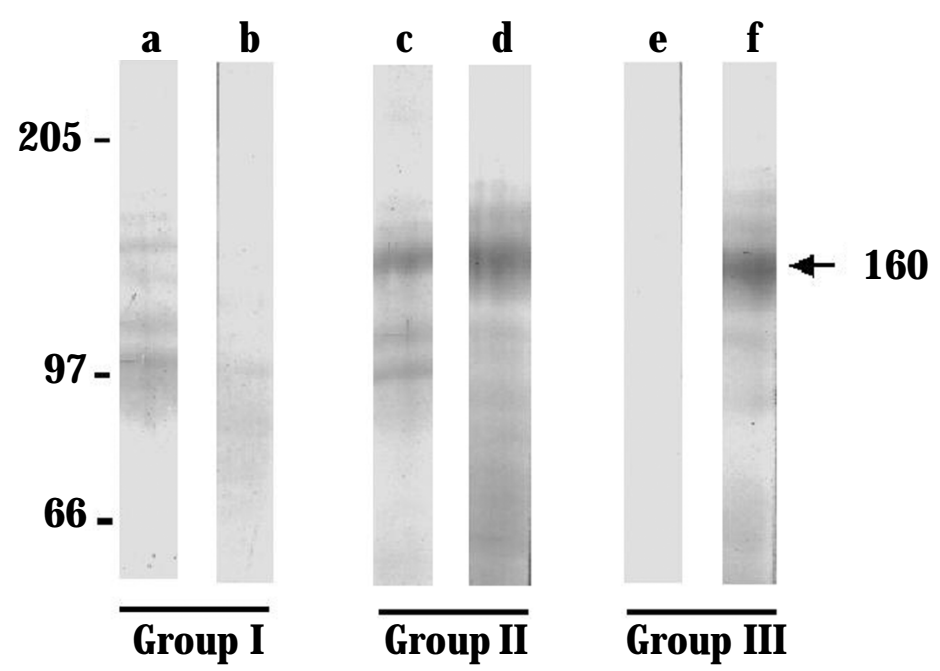

Figure 1 - One-dimension immunoblot of the serum from early acute (Group I), late acute (Group II) and chronic infection (Group III) with Trypanosoma cruzi. Lanes $a, c$ and e show IgM reactivity and lanes b, $d$ and $f$ show the IgG profile against excreted-secreted antigens. The arrow points to the $160 \mathrm{kDa}$ band and molecular weight markers ( myosin 205kDa, phosphorylase b $97 \mathrm{kDa}$ and albumin bovine $66 \mathrm{kDa}$ ) are shown on the left. These data are representative of the all sera samples. 
of the blotting, as shown by the arrow heads ( Figure 2a). A similar IgM profile was observed in late acute infection (Figure 2b).

The IgG detected in the late acute infection also presented a scattered reaction ranging from $\mathrm{pI} 5.8$ to 6.7 and 70 to $180 \mathrm{kDa}$. However, IgG showed a slightly distinct pattern when compared to IgM. In the late acute infection four defined spots, with pI 6.2-6.7, were recognized by IgG in the 150-160kDa region, as shown by the arrow heads (Figure 2c). Serum samples from chronic patients, when analyzed for specific IgG in 2D immunoblotting showed strong reaction against the four spots described above. Among these dots, a dominant responsiveness was observed against the spot located atpI 6.2 - 6.4 in most of the chronic patient samples (Figure 2d). The frequency of bands recognized in all sample sera were similar (Table 1).

Table 1 - Frequency for recognition in 2D gel of $160 \mathrm{kDa}$ protein, according to chagasic and non-chagasic serum samples.

\begin{tabular}{|c|c|c|c|c|}
\hline \multirow{3}{*}{ Serum Samples } & \multicolumn{4}{|c|}{ Isoforms (pI) } \\
\hline & \multicolumn{2}{|c|}{$5.8-6.7$} & \multicolumn{2}{|c|}{$6.2-6.7$} \\
\hline & IgG & IgM & IgG & IgM \\
\hline Early acute phase & $0 \%$ & $100 \%$ & - & - \\
\hline Late acute phase & $100 \%$ & $100 \%$ & - & - \\
\hline Chronic phase & - & $\mathrm{NR}^{*}$ & $100 \%$ & $\mathrm{NR}$ \\
\hline Non-chagasic & $\mathrm{NR}$ & $\mathrm{NR}$ & $\mathrm{NR}$ & $\mathrm{NR}$ \\
\hline
\end{tabular}

As a complementary experiment, 2D membranes were probed with polyclonal antibodies generated against a fragment of T. cruzi $160 \mathrm{kDa}$ recombinant protein (kindly provided by Dr. Eufrozina S. Umezawa, IMT-USP, São Paulo). Our results showed that the four spots located at the range of $150-160 \mathrm{kDa}$ and pI $6.2-6.7$ were equally immunostained by the $160 \mathrm{kDa}$ specific antibody (data not shown).

\section{DISCUSSION}

In this study, we grouped the infected patients into early acute, late acute and chronic phases of T. cruzi infection. This classification serves for academic purposes and does not necessarily represent the epidemiological scenario of the disease. Approximately $50 \%$ of the chagasic population in endemic areas have the indeterminate form ofChagas' disease. The acute phase frequentlygoes unperceived due to a lack of clinical symptoms, the majority of the infected population is unaware of their health condition ${ }^{25}$.

The epidemiological features and peculiarities of the disease in endemic areas represent a challenge for screening healthy blood donors. In Uberlândia, MG, Brazil, a well characterized endemic area, up to $4 \%$ of the volunteers for blood donation are rejected due to inconclusive conventional serology for Chagas' disease. This data encouraged us to search for more efficient diagnostic tools, especially in those cases where conventional techniques can not provide a definitive result.

Trypanosoma cruzi as well as other trypanosomatids synthesize and secrete a broad variety of molecules with biological activity during their lifecycle. The fact that T. cruzi is transmitted by an insect vector and is able to invade several cell types within the host indicates the requirement of a very versatile adaptive system or systems. The specialized coat of glycoproteins and
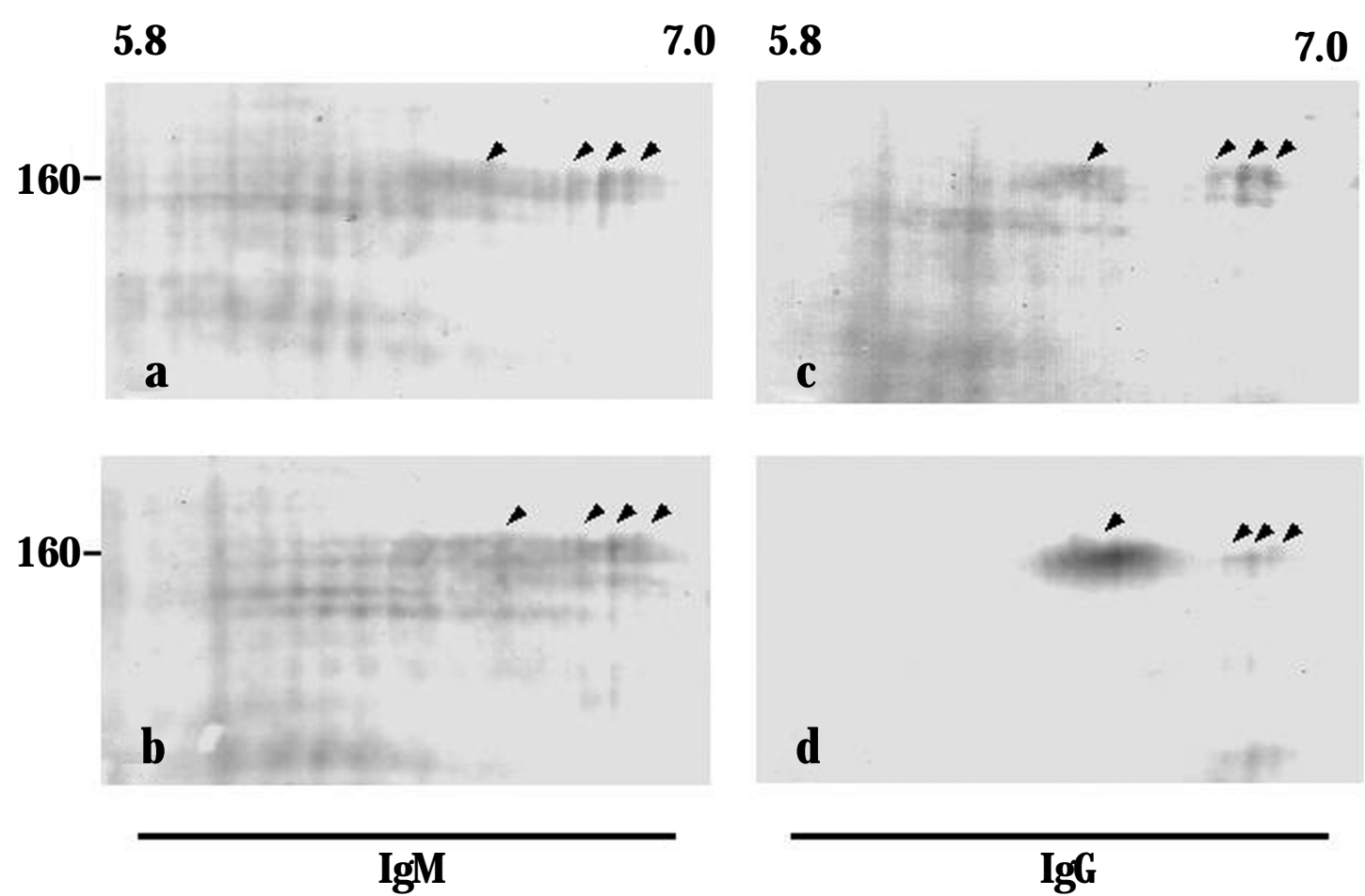

Figure 2 - Two-dimension immunoblot of chagasic patient sera. Figures 2a and 2b show antigens detected by IgM during the early acute and late acute infections respectively. Figures $2 \mathrm{c}$ and $2 \mathrm{~d}$ represent IgG reactivity during the late acute and the chronic infections respectively. The arrowheads point to $160 \mathrm{kDa}$ protein isoforms. These data are representative of the all sera samples. 
glycolipis on the parasite surface together with secreted proteins all have a crucial role in this environmental transition and adaptation ${ }^{18}$.

Many of these secreted molecules belong to the T. cruzi transialidase (TS) family ${ }^{7}$. During the early stage of infection an intense shedding of TS molecules (also called shed acute phase antigens [SAPA]), elicits the production of specific antibodies that function as markers of acute infection ${ }^{1}$. Recent publications have supported that transialidase family antigens are associated to cellular invasion, due to their capacity to bind cell receptors and extracellular matrix protein ${ }^{1017}$. TS proteins have also been implicated in immune response modulation leading to a down regulation of $\mathrm{T}$ cells activity ${ }^{12}$. Later in the disease course, a clear detection of antibodies against the $160 \mathrm{kDa}$ secreted protein is considered indicative of chronic Chagas' disease $\mathrm{s}^{32}$.

Following the criteria described above, the pattern of specific IgM produced during the earlyacute infection suggests that these antibodies are directed against TS repeats contained in SAPA complex ${ }^{15}$. During the early acute phase, most samples contained IgG that weakly recognized antigens below $100 \mathrm{kDa}$. Further investigations will focus on the characterization of this antibody population.

In the late acute phase IgM and IgG revealed strong bands of approximately $150-160 \mathrm{kDa}$. A lower intensity of reaction was observed in other bands above and below the 150-160 kDa range that probably represents antibodies against TS repeats present in SAPA molecules.

As expected, no IgM was detected in the chronic infection and the $160 \mathrm{kDa}$ protein became the dominant antigen revealed by the IgG immunoassay.

Two-dimensional analysis of ES antigens immunolabeled by human chagasic serum revealed several spots in the $80-110 \mathrm{kDa}$ region with a wide range of isoelectric points ( $\mathrm{pI}$ between $5.4-6.7)^{22}$. In the present work, the IgG profile displayed dominant responsiveness against the dot located at $160 \mathrm{kDa}$ and $\mathrm{pI}$ 6.2-6.4, which was the major immunological target in secreted antigens during the chronic infection (Figure 2d). Five out of ten samples from chronic patients remained reactive to TS repeats in various degrees. These data suggest thatTSimmune stimuli can remain active through the course of the disease leading to a long-lasting specific antibody production.

The combined analysis of 1D and 2D immunoblots during the early and late acute phase revealed a high level of complexity in the T. cruzi excreted-secreted antigen recognition. The ladderlike pattern, usually containing six bands, observed in 1D blots exposed approximately thirtyimmunoreactive spots when analyzed by $2 \mathrm{D}$ blots. This data in addition to the lack of clear definition in the spots' shape indicate a considerable degree of modification in this group of antigens. The uniformity and definition of these spots suggest the presence of a highly repetitive protein motif and may also indicate that this group of antigens undergoes a considerable degree of post-translational modifications.

It is noteworthy that IgM and/or IgG antibodies recognized four dots at $160 \mathrm{kDa}$ through all phases of Chagas' disease in all infected patient samples, as observed in 2D analysis ( Figure 2, arrowheads). These dots represent isoforms of $160 \mathrm{kDa}$ protein, as indicated by specific polyclonal antibody reaction. In contrast to sera from chronicallyinfected patients the $160 \mathrm{kDa}$ immunoreaction was not clearly visible in $1 \mathrm{D}$ immunoblot during the acute phase (Figure 1a), this is probably due to a massive antibody response against TS repeats that masked the $160 \mathrm{kDa}$ band.

No variation in mass was observed between the four isoforms of the $160 \mathrm{kDa}$ protein. However, each isoform has a particular isoelectric focusing point, which might be related to modifications, such as phosphorylation that alter the proteins' electric charge.

It is interesting to observe how the immune system shifts the response directed to secreted antigens. The SAPA responsiveness slowly decreased during the progress of disease ${ }^{14}$, while $160 \mathrm{kDa}$ complex became the major excreted-secreted immunogen.

In summary, we have shown that T. cruzi excreted-secreted antigens comprise a complex mixture of antigens, as demonstrated by high-resolution 2D immunoblotting. Our data, although analyzing a small number of patients, correlated with other studies indicating that TESA is a highly efficient tool for Chagas' disease diagnosis in either acute or chronic stages.

\section{ACKNOWLEDGMENTS}

We are indebted to Dr. Eufrozina S. Umezawa from the Institute of Tropical Medicine of São Paulo, for the help with antigen production and standardization and to Dr. Samantha Donnelly for critically reading this manuscript.

\section{REFERENCES}

1. Affranchino JL, Ibanez CF, Luquetti AO, Rassi A, Reyes MB, Macina RA, Aslund L, Pettersson U, Frasch AC. Identification of a Trypanosoma cruzi antigen that is shed during the acute phase of Chagas' disease. Molecular and Biochemical Parasitology 34:221-228, 1989.

2. Andrews NW. The acid-active hemolysin of Trypanosoma cruzi. Experimental Parasitology 71:241-244, 1990.

3. Camargo ME, SG, CE, Silveira AC. [ Serological survey of the prevalence of Chagas' infection in Brazil, 1975/1980]. Revista do Instituto de Medicina Tropical de São Paulo 26:192-204, 1984.

4. Campetella 0, Martinez J, Cazzulo JJ. A major cysteine proteinase is developmentally regulated in Trypanosoma cruzi. FEMS Microbiology Letters 55:145-149, 1990.

5. Chiller TM, Samudio MA, Zoulek G. IgG antibody reactivity with Trypanosoma cruzi and Leishmania antigens in sera of patients with Chagas' disease and leishmaniasis. The American Journal of Tropical Medicine and Hygiene 43:650-656, 1990.

6. Cohen JE, Gurtler RE. Modeling household transmission of American trypanosomiasis. Science 293:694-698, 2001.

7. Colli W. Trans-sialidase: a unique enzyme activity discovered in the protozoan Trypanosoma cruzi. The FASEB Journal 7:1257-1264, 1993.

8. Gazzinelli G, Brener Z. Immunological aspects of the morbidity of human Chagas' disease. Research in Immunology 142:167-169, 1991.

9. Gazzinelli RT, Galvao LM, Krautz G, Lima PC, Cancado JR, Scharfstein J, Krettli AU. Use of Trypanosoma cruzi purified glycoprotein (GP57/51) or trypomastigote-shed antigens to assess cure for human Chagas' disease. The American Journal of Tropical Medicine and Hygiene 49:625-635, 1993. 
10. Giordano R, Fouts DL, Tewari D, Colli W, Manning JE, Alves MJ. Cloning of a surface membrane glycoprotein specific for the infective form of Trypanosoma cruzi having adhesive properties to laminin. The Journal of Biological Chemistry 274:3461-3468, 1999.

11. Gomes YM. PCR and sero-diagnosis of chronic Chagas' disease. Biotechnological advances. Applied Biochemistry and Biotechnology 66:107-119, 1997

12. Gorelik G, Cremaschi G, Borda E, Sterin-Borda L. Trypanosoma cruzi antigens down-regulate $\mathrm{T}$ lymphocyte proliferation by muscarinic cholinergic receptor-dependent release of PGE2. Acta Physiologica Pharmacologica at Therapeutica Latinoamericana 48:115-123, 1998.

13. Greig S, Ashall F. Electrophoretic detection of Trypanosoma cruzi peptidases. Molecular and Biochemical Parasitology 39:31-37, 1990.

14. Jazin EE, Luquetti AO, Rassi A, Frasch AC. Shift of excretory-secretory immunogens of Trypanosoma cruzi during human Chagas' disease. Infection and Immunity 59:2189-191, 1991.

15. Kesper NJ, AK, Stolf AM, Umezawa ES. Immunoblot analysis of trypomastigote excreted-secreted antigens as a tool for the characterization of Trypanosoma cruzi strains and isolates. The Journal of Parasitology 86:862-867, 2000

16. Krautz GM, Galvao LMC, Cançado JR, Guevara-Espinoza A, Ouaissi A, Krettli AU. Use of a 24-kilodalton Trypanosoma cruzi recombinant protein to monitor cure of human Chagas' disease. Journal of Clinical Microbiology 33:2086-2090

17. Magdesian MH, Giordano R, Ulrich H, Juliano MA, Juliano L, Schumacher RI, Colli W, Alves MJ. Infection by Trypanosoma cruzi. Identification of a parasite ligand and its host cell receptor. The Journal of Biological Chemistry 276:19382-19389, 2001.

18. McConville MJ, Mullin KA, Ilgoutz SC, Teasdale RD. Secretory pathway of trypanosomatid parasites. Microbiology and Molecular Biology Reviews 66:122-154, 2002

19. Medrano NM, Luz MR, Cabello PH, Tapia GT, Van LF, Araujo JT. Acute Chagas' disease: plasma levels of alpha-2-macroglobulin and C-reactive protein in children under 13 years in a high endemic area of Bolivia. Journal of Tropical Pediatrics 42:68-74, 1996.

20. Moncayo A. Progress towards the elimination of transmission of Chagas disease in Latin America. World Health Statistics Quarterly 50:195-198, 1997.

21. Nakazawa M, Rosa DS, Pereira VR, Moura MO, Furtado VC, Souza WV, Barros MN, Abath FG, Gomes YM. Excretory-secretory antigens of Trypanosoma cruzi are potentially useful for serodiagnosis of chronic Chagas' disease. Clinical and Diagnostic Laboratory Immunology 8:10241027, 2001
22. Ouaissi MA, Taibi A, Cornette J, Velge P, Marty B, Loyens M, Esteva M, Rizvi FS, Capron A. Characterization of major surface and excretory-secretory immunogens of Trypanosoma cruzi trypomastigotes and identification of potential protective antigen. Parasitology 100: 115-124, 1990.

23. Pereira ME. A developmentally regulated neuraminidase activity in Trypanosoma cruzi. Science 219:1444-1446, 1983.

24. Pless M, Juranek D, Kozarsky P, Steurer F, Tapia G, Bermudez H. The epidemiology of Chagas' disease in a hyperendemic area of Cochabamba, Bolivia: a clinical study including electrocardiography, seroreactivity to Trypanosoma cruzi, xenodiagnosis, and domiciliary triatomine distribution. American Journal of Tropical Medicine and Hygiene 47:539. 546, 1992.

25. Prata A. Clinical and epidemiological aspects of Chagas disease. The Lancet Infectious Diseases 1:92-100, 2001.

26. Schmunis GA, Zicker F, Pinheiro F, Brandling BD. Risk for transfusiontransmitted infectious diseases in Central and South America. Emerging Infectious Diseases 4:5-11, 1998.

27. Segura EL, Cura EN, Estani SA, Andrade J, Lansetti IC, RA, Campanini A, Blanco $\mathrm{SB}$, Gurtler RE, Alvarez M. Long-term effects of a nationwide control program on the seropositivity for Trypanosoma cruzi infection in young men from Argentina. American Journal of Tropical Medicine and Hygiene 62:353-362, 2000.

28. Umezawa ES, Bastos SF, Camargo ME, Yamauchi LM, Santos MR, Gonzalez A, Zingales B, Levin MJ, Sousa O, Rangel AR, Silveira JF. Evaluation of recombinant antigens for serodiagnosis of Chagas' disease in South and Central America. Journal of Clinical Microbiology 37:1554-1560, 1999.

29. Umezawa ES, Bastos SF, Coura JR, Levin MJ, Gonzalez A, Rangel AR, Zingales B, Luquetti A0, Silveira JF. An improved serodiagnostic test for Chagas' disease employing a mixture of Trypanosoma cruzi recombinant antigens. Transfusion 43:91-97, 2003.

30. Umezawa ES, Nascimento MS, Kesper N, Coura JR, Borges PJ, Junqueira AC, Camargo ME. Immunoblot assay using excreted-secreted antigens of Trypanosoma cruzi in serodiagnosis of congenital, acute, and chronic Chagas' disease. Journal of Clinical Microbiology 34:2143-2147, 1996.

31. Umezawa ES, Nascimento MS, Stolf AM. Enzyme-linked immunosorbent assay with Trypanosoma cruzi excreted-secreted antigens (TESA-ELISA) for serodiagnosis of acute and chronic Chagas' disease. Diagnostic Microbiology and Infectious Disease 39:169-176, 2001.

32. Umezawa ES, Shikanai YM, Stolf AM. Changes in isotype composition and antigen recognition of anti-Trypanosoma cruzi antibodies from acute to chronic Chagas disease. Journal of Clinical Laboratory Analysis 10:407-413, 1996.

33. Yokoyama YJ, Pral EM, Oliveira J0, Alfieri SC, Stolf AM. Trypanosoma cruzi: identification of proteinases in shed components of trypomastigote forms. Acta Tropica 57:307-315, 1994. 